\title{
Genetic characterization and nitrogen fixation capacity of Rhizobium strains on common bean
}

\author{
Tehuni Orlando González ${ }^{(1)}$, João Carlos Campanharo(2) and Eliana Gertrudes de Macedo Lemos ${ }^{(2)}$
}

\begin{abstract}
(1)Universidad Central de Venezuela, Facultad de Agronomía, Vía El Limón, Código Postal 2101, Maracay, Estado Aragua, Venezuela. E-mail: tehuni@cantv.net (2)Universidade Estadual Paulista, Faculdade de Ciências Agrárias e Veterinárias, Departamento de Tecnologia, Via de Acesso Prof. Dr. Paulo Donato Castellane, s/no, CEP 14884-900 Jaboticabal, SP, Brazil. E-mail: jccamp@fcav.unesp.br, egerle@fcav.unesp.br
\end{abstract}

\begin{abstract}
This study aimed to genetically characterize four new Rhizobium strains, and to evaluate their nodulation and fixation capacity compared to commercial strains and to native rhizobia population of a Brazilian Rhodic Hapludox. Two experiments were carried out in randomized blocks design, under greenhouse conditions, in 2007. In the first experiment, the nodulation and nitrogen fixation capacity of new strains were evaluated, in comparison to the commercial strains CIAT-899 and PRF-81 and to native soil population. It was carried out in plastic tubes filled with vermiculite. DNA extractions and PCR sequencing of the intergenic space were made from the isolated pure colonies, in order to genetically characterize the strains and the native rhizobia population. In the second experiment, the nodulation and productivity of common beans Perola cultivar were determined, with the use of evaluated strains, alone or in mixture with PRF-81 strain. It was carried out in pots filled with soil. The native soil population was identified as Rhizobium sp. and was inefficient in nitrogen fixation. Three different Rhizobium species were found among the four new strains. The LBMP-4BR and LBMP-12BR new strains are among the ones with greatest nodulation and fixation capacity and exhibit differential responses when mixed to PRF-81.

Index terms: Phaseolus vulgaris, biological nitrogen fixation, intergenic space, phylogeny, sequencing, soil rhizobia population.

\section{Caracterização genética e capacidade de fixação de nitrogênio de estirpes de Rhizobium em feijoeiro}

Resumo - O objetivo deste trabalho foi a caracterização genética de quatro novas estirpes de Rhizobium e a avaliação de sua capacidade de fixação de $\mathrm{N}_{2}$ e nodulação, comparadas a estirpes comerciais e à população nativa de rizóbios de um Latossolo Vermelho. Dois experimentos foram conduzidos em blocos ao acaso, em casa de vegetação. No primeiro experimento, conduzido em tubetes com vermiculita, avaliaram-se a nodulação e a capacidade de fixação das novas estirpes, em comparação com as estirpes comerciais CIAT-899 e PRF-81 e com a população nativa do solo. Das colônias puras isoladas, extraiu-se o DNA genômico e realizou-se o seqüenciamento do espaço intergênico, para a caracterização genética das estirpes e da população nativa de rizóbios. O segundo experimento foi realizado em vasos com solo, para determinação da produtividade e da nodulação do feijoeiro, cultivar Pérola, com o uso das estirpes isoladamente ou em mistura com a PRF-81. A população nativa do solo foi identificada como Rhizobium sp. e se mostrou ineficiente na fixação de nitrogênio. Foram encontradas três espécies de Rhizobium entre as quatro novas estirpes. As estirpes LBMP-4BR e LBMP-12BR estão entre as que têm maior capacidade de nodulação e fixação de $\mathrm{N}_{2}$, e apresentam respostas diferenciadas quando misturadas à PRF-81.

Termos para indexação: Phaseolus vulgaris, fixação biológica de nitrogênio, espaço intergênico, filogenia, seqüenciamento, população nativa de rizóbios.

\section{Introduction}

Biological nitrogen fixation is a worldwide economical and sustainable alternative for nitrogen supply to legume crops. It may reduce the expenses with chemical nitrogen fertilizers, as well as eliminating the negative impact of them on the environment (Straliotto et al., 2002).
To take advantage of common bean (Phaseolus vulgaris L.) nitrogen biofertilizer, several studies have sought to identify efficient and competitive strains of rhizobia to cope the nitrogen requirements of this important crop. Unfortunately, biological nitrogen fixation in common bean field crops has exhibited unstable behavior (Mostasso et al., 2002; Hafeez et al., 2005; Soares et al., 2006). 
Several approaches have been used to obtain new rhizobia strains which exhibit better biological nitrogen fixation responses on common bean. Typically, these strains are evaluated individually (Hungria et al., 2003; Soares et al., 2006) or in mixture with other strains (Hassan et al., 2004; Hafeez et al., 2005; Raposeiras et al., 2006).

Since June 1998, two Rhizobium tropici strains SEMIA 4077 (CIAT-899) and SEMIA 4080 (PRF-81) - have their use recommended, in mixture, for inoculation on common bean crops, in Brazil (Hungria et al., 2000). Nevertheless, further research to isolate new strains with genetic diversity and nitrogen fixation efficiency has been carried out. In this sense, Mostasso et al. (2002) and Hungria et al. (2003) evaluated the H12 strain (SEMIA 4088), and concluded that it was efficient and competitive, providing high yield potential to common beans.

Raposeiras et al. (2006) and Soares et al. (2006) carried out studies on agronomic efficiency of new Rhizobium strains in common bean, in different Brazilian environments, and identified only strains that made possible productivities similar to the obtained with CIAT-899 strain inoculation.

Polymerase chain reaction (PCR) has enabled great advances in the study of taxonomy and genetic diversity of rhizobia, because this technique permits the sequencing and comparison of defined fragments of nucleotide sequences, such as ribosomal genes (16S and 23S rRNA) and intergenic spaces (16S-23S rRNA), which have sufficient variability for detecting differences among genus and species (Laguerre et al., 1996; Chueire et al., 2003; Young et al., 2004).

The objective of this work was to genetically characterize four new Rhizobium strains, previously selected for their effectiveness in nitrogen fixation, and to evaluate their nodulation and fixation capacity compared to commercial strains and to native rhizobia soil population of a Rhodic Hapludox.

\section{Materials and Methods}

Two experiments were performed, in order to genetically characterize four new rhizobia strains, previously isolated from common bean nodules (two strains from Brazil and two from Venezuela, Table 1); and, also, to evaluate their nodulation and fixation capacity compared to two commercial strains and to native rhizobial population of a Brazilian Latossolo Vermelho (Rhodic Hapludox). Besides that the productivity and nodulation of common bean with the use of these strains alone and in mixture with PRF-81 strain were evaluated. The experiments were carried out using a randomized blocks design, with three replicates, under greenhouse conditions $\left(28 / 24^{\circ} \mathrm{C}\right.$ day-night, and $60 \pm 5 \% \mathrm{RH}$ ), from February to July 2007, at Universidade Estadual Paulista (Unesp), in Jaboticabal, SP, Brazil.

The first experiment was driven in February and March, for the genetic characterization of strains and native rhizobia population. The four new strains, the two commercial ones and seven serial dilutions of the soil were inoculated to common bean plants cultivated in plastic tubes with $250 \mathrm{~cm}^{3}$ capacity filled with autoclave-sterilized vermiculite, $\mathrm{pH}$ 6.8. Thirteen treatments were used to evaluate strains and native rhizobia population capacity to nodulate and to fix nitrogen on common bean plants: seven serial dilutions $\left(10^{-1}\right.$ to $\left.10^{-7}\right)$ of the Rhodic Hapludox, in $0.85 \%$ saline solution, prepared according to Vincent (1970); four new strains (LBMP $3 \mathrm{VE}, 4 \mathrm{VE}, 4 \mathrm{BR}$, and 12BR) (Table 1), and two commercial strains (CIAT-899 and PRF-81). The inoculant treatments were prepared in liquid formulation from yeast-extract mannitol (YM)

Table 1. Strain identification, land use systems (LUS), localization, soil characteristics and relevant management of the four new strains isolated from common bean in Brazil (BR) and Venezuela (VE).

\begin{tabular}{|c|c|c|c|}
\hline $\begin{array}{l}\text { Strain } \\
\text { identification }\end{array}$ & LUS/town/states/country & $\begin{array}{l}\text { Geographic } \\
\text { coordinates }\end{array}$ & Soil characteristics \\
\hline LBMP-3VE & $\begin{array}{l}\text { Common bean-corn, conventional tillage, Sabaneta, } \\
\text { Barinas, Venezuela }\end{array}$ & $\begin{array}{r}8^{\circ} 45^{\prime} 31.75^{\prime \prime} \mathrm{N} \\
69^{\circ} 55^{\prime} 12.36^{\prime \prime} \mathrm{W}\end{array}$ & Acid, $\mathrm{pH} 6.2$, without lime application \\
\hline LBMP-4VE & $\begin{array}{l}\text { Common bean-corn, conventional tillage, Tarragona, } \\
\text { Monagas, Venezuela }\end{array}$ & $\begin{array}{l}9^{\circ} 40^{\prime} 14.47^{\prime \prime} \mathrm{N} \\
63^{\circ} 50^{\prime} 59.50^{\prime \prime} \mathrm{W}\end{array}$ & Acid, pH 5.5, with lime application \\
\hline LBMP-4BR & $\begin{array}{l}\text { Corn minimum tillage, } \\
\text { Cristalina, GO, Brazil }\end{array}$ & $\begin{array}{l}16^{\circ} 10^{\prime} 56.93^{\prime \prime S} \\
47^{\circ} 28^{\prime} 30.34^{\prime \prime} \mathrm{W}\end{array}$ & Acid, pH 5.8, with lime application \\
\hline LBMP-12BR & Natural grass without crop, Pouso Alegre, MG, Brazil & $\begin{array}{l}22^{\circ} 13^{\prime} 51.18^{\prime \prime S} \\
45^{\circ} 53^{\prime} 19.98^{\prime \prime} \mathrm{W}\end{array}$ & Acid, pH 5.4 without lime application \\
\hline
\end{tabular}


medium, incubated at $28^{\circ} \mathrm{C}$ in a shaker $(120 \mathrm{rpm})$ for 48 hours (Vincent, 1970). The number of cells was determined by optic density using a photoelectric colorimeter, resulting in a formulation ratio of approximately $10^{9}$ cells $\mathrm{mL}^{-1}$ (colony formation units method).

The plot was constituted by three plastic tubes, with two seeds each, of common bean cultivar Pérola (Yokoyama et al., 1999) previously surface-sterilized with $95 \%$ ethanol, for one min, and 3\% sodium hypochlorite solution for five min, then, washed seven times with sterile distilled water. Six days after planting, on emergence stage, the plants were thinned out leaving one seedling per tube. Then, the treatments were applied by adding $1 \mathrm{~mL}$ of the serial dilution treatments and the inoculant formulations, at the plant base.

During the growth stage, regular irrigations on plants were done with sterile distilled water to maintain the tubes close to field capacity. In all treatments, nutritional solution, without nitrogen, was applied weekly (Gibson, 1987).

At the flowering stage, 38 days after planting, plants were harvested, and the presence of nodules on plants treated with serial dilutions was examined, to determine the rhizobial populations of the Rhodic Hapludox, using the most probable number (MPN) method, according to Vincent (1970). For the inoculated strain treatments, the number (NN) and the dry weight of nodules (DWN) per plant, shoot dry weight per plant (SDW) and shoot total nitrogen per plant (STN) were determined. The STN was measured using the semi-micro Kjeldahl method (Silva \& Queiroz, 2006). Results were submitted to analysis of variance, using the F test, and means were compared using the Scott-Knott test (probability set to $5 \%$ ) using the analysis of variance system (SISVAR) software (Ferreira, 1999).

For all the inoculated treatments (serial dilution treatments and the evaluated strains), the nodules were used to provide pure colony isolates used for genetic characterization through sequencing of the intergenic space (ITS) between the 16S and 23S rRNA genes. For accomplishing that, two nodules from each plant were surface-sterilized, as described above for seeds. Nodules were immediately squeezed in Petri dishes containing yeast-extract mannitol agar(YMA) medium, with Congo red (Vincent, 1970), and then incubated in a biological oxygen demand chamber (BOD), at $28^{\circ} \mathrm{C}$, for 48 hours, and replicated several times until pure isolate colonies were obtained.
The pure isolate nodule colonies from the serial dilutions treatments were divided into homogeneous groups, based on the microbiological characteristics of the isolates (Soares et al., 2006).

The homogeneous groups of native isolates, from soil and from the four evaluated strains, were cultivated in tryptone yeast-extract (TY) medium with agar (Beringer, 1974), in a BOD chamber at $28^{\circ} \mathrm{C}$, and replicated every other day, five successive times. Next, the bacteria were grown in $50 \mathrm{~mL}$ of liquid TY medium, at $28^{\circ} \mathrm{C}$, and cultured in a shaker $(120 \mathrm{rpm})$ for 48 hours.

Genomic DNA was extracted and purified from cells cultivated in liquid TY medium, according to Sambrook et al. (1989) method. Bacterial DNA was amplified on a PCR thermal cycler, using primers FGPS 1490 (5'-TGCGGCTGGATCACCTCCTT-3') and FGPS132' (5'-CCGGGTTTCCCCATTCGG-3'). These primers amplify the intergenic space between the 16S and 23S rRNA genes (Laguerre et al., 1996).

The PCR reaction was carried out in a final volume of $20 \mu \mathrm{L}$, containing $12.7 \mu \mathrm{L}$ sterilized ultrapure water; $0.4 \mu \mathrm{L}$ dNTPs mixture $(1.5 \mathrm{mM}$ per nucleotide); $2 \mu \mathrm{L}$ buffer $1 \mathrm{X}$ [20 mMTris- $\mathrm{HCl}$ (pH 8.4), $50 \mathrm{mM} \mathrm{KCl}] ; 0.6 \mu \mathrm{L}$ of $\mathrm{MgCl}_{2}(50 \mathrm{mM}) ; 1 \mu \mathrm{L}$ each primer $\left(5 \mathrm{pmol} \mu \mathrm{L}^{-1}\right) ; 0.3 \mu \mathrm{L}$ Taq DNA polymerase

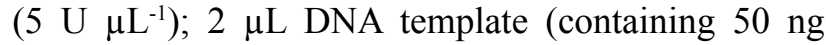
approximately).

The amplification profile consisted of: an initial denaturation step, at $95^{\circ} \mathrm{C}$ for $3 \mathrm{~min} ; 35$ cycles of denaturation $\left(1 \mathrm{~min}\right.$ at $\left.94^{\circ} \mathrm{C}\right)$, annealing $(1 \mathrm{~min}$ at $55^{\circ} \mathrm{C}$ ) and extension $\left(2 \mathrm{~min}\right.$ at $\left.72^{\circ} \mathrm{C}\right)$, followed by a final extension at $72^{\circ} \mathrm{C}$, for $3 \mathrm{~min}$, and maintenance at $4^{\circ} \mathrm{C}$ (Laguerre et al., 1996). The PCR procedure was performed twice.

The PCR products were purified and sequenced directly, using ABI PRISM Big Dye Terminator kit (Applied Biosystems, USA), according to manufacturer's instruction, by a capillary sequencer (model ABI 3700). The above-described primers and PCR amplification profile were also used for sequencing.

Sequence quality was verified using Sequencing Analysis 3.4 software (Applied Biosystems, Foster City, CA, USA). Electropherogram analysis was done using Phred, Phrap and Consed programs (Gordon et al., 1998). Sequence selection was made using ContGEN, with a minimum requirement level of 400 bases and a 
Phred quality greater than 20 . The consensus sequences were obtained by overlap of $50 \mathrm{bp}$, using the software cited above.

Nucleotide sequences were submitted to the GenBank of National Center for Biotechnology Information (NCBI), and were subjected to nucleotide similarity comparison. The basic local alignment search tool (Blast) (Altschul et al., 1997) was used for sequence comparison. For multiple sequence alignments of the 16S-23S rRNA genes obtained in this study, as well as others selected from the database, a global alignment was generated using BioEdit (Hall, 1999) by selecting the clustal $\mathrm{x}$ alignment option (Thompson et al., 1997).

Beginning with the aligned sequences, a phylogenetic tree was constructed using the Neighbor-Joining algorithm in MEGA V. 2.1 software (Kumar et al., 2001), with 1,000 bootstrap replicates. To generate the tree, only the commercial strain CIAT-899 was included, because the PRF-81 intergenic sequence was not available on GenBank.

The second experiment permitted the evaluation of nodulation and productivity of common beans infected with the studied strains, alone and in mixture with PRF-81 strain, in comparison to the inoculation with CIAT-899 and PRF-81 commercial strains, in a medium-texture Rhodic Hapludox condition. The experiment was conducted from April to July and was carried out in plastic pots with $7.5 \mathrm{dm}^{3}$ capacity. The pots were filled with soil which had not cultured crops for the previous five years. The soil analysis showed: $\mathrm{pH}$ in $\mathrm{CaCl}_{2}, 5.9 ; \mathrm{H}+\mathrm{Al}, 11 \mathrm{mmol}_{\mathrm{c}} \mathrm{dm}^{-3}$; $\mathrm{Ca}$, $\mathrm{Mg}$ and $\mathrm{K}, 30,18$ and $2.4 \mathrm{mmol}_{\mathrm{c}} \mathrm{dm}^{-3}$, respectively; $\mathrm{P}$, $32 \mathrm{mg} \mathrm{dm}^{-3}$; organic matter, $11 \mathrm{~g} \mathrm{dm}^{-3} ; \mathrm{Cu}, 0.6 \mathrm{mg} \mathrm{dm}^{-3}$; $\mathrm{Fe}, 8 \mathrm{mg} \mathrm{dm}^{-3} ; \mathrm{Mn}, 5.2 \mathrm{mg} \mathrm{dm}^{-3} ; \mathrm{Zn}, 0.6 \mathrm{mg} \mathrm{dm}^{-3}$; and $\mathrm{V}, 81 \%$. Based on these soil characteristics and on common bean nutritional requirements (Oliveira et al., 2002), it was unnecessary to apply lime. Before planting, $200 \mathrm{~kg} \mathrm{ha}^{-1}$ of the commercial fertilizer NPK (0-20-20) was applied.

Thirteen treatments were evaluated: the four new Rhizobium strains (LBMP 3VE, 4VE, 4BR and 12BR) (Table 1); two commercial strains (CIAT-899 and PRF-81), inoculated alone; a 1:1 mixture of the two commercial strains; four treatments containing a $1: 1$ mixture of each new LBMP strain and PRF-81; and two uninoculated controls, one without nitrogen and the other with $70 \mathrm{~kg} \mathrm{ha}^{-1}$ nitrogen. The nitrogen source used was urea, with one half applied after thinning, and the other half applied 25 days after planting.

The inoculant treatments were prepared as described for the first experiment, and $1 \mathrm{~mL}$ was applied to the seeds (previously surface-sterilized, as described above), before planting. The cultivar used was also Pérola, planted with two seeds per pot; leaving only one seedling after six days of planting. Irrigation was done using the drop irrigation system, irrigating up to field capacity, when the tensiometers indicated $40 \mathrm{kPa}$.

The plot size consisted of six plants, two of which were harvested at flowering, 38 days after planting, and the number $(\mathrm{NN})$ and dry weight of nodules (DWN) per plant, shoot dry weight per plant (SDW) and shoot total nitrogen per plant (STN) were determined. The STN was measured using the semi-micro Kjeldahl method.

At harvest, 81 days after planting, the four remaining plants were collected, and the productivity of grains per plant $(\mathrm{PG})$, with the humidity corrected to $13 \%$, and total nitrogen in grains (TNG) were determined. Results were submitted to analysis of variance, and means were compared using the Scott-Knott test, as described for first experiment.

\section{Results and Discussion}

In the first experiment, the native rhizobia population of the Rhodic Hapludox was around $0.64 \times 10^{4}$ to $4.80 \times 10^{4}$ cells g-1 of soil. These results agreed with those of Soares et al. (2006), in which relatively high population of rhizobia was found in an acid soil of Minas Gerais State. However, the absence of a rhizobia population in acid Brazilian Cerrado soil, observed by Raposeiras et al. (2006), suggests that these microorganisms exhibit high levels of variability in tropical conditions.

The analysis of variance for number and dry weight of nodules per plant, shoot dry weight per plant and shoot total nitrogen per plant showed no statistical differences among inoculated strain treatments. These results probably could be explained by the adequate $\mathrm{pH}$ conditions in vermiculite media, close to 6.8 (Vincent, 1970), and by the uniform application of fertilizer without nitrogen in nutritional solution (Gibson, 1987), which permitted the growth of all strains without limitations of $\mathrm{pH}$ and nutrients required to express their ability on nodulation and nitrogen fixation. 
The native isolates from the serial dilutions of Rhodic Hapludox produced a single morphologically homogeneous group of colony, which was yellow, displayed fast growth (three days), and had a diameter larger than $2 \mathrm{~mm}$, high exopolysaccharide production and acidic alterations of growth culture.

Sequencing of the intergenic space between the $16 \mathrm{~S}$ and $23 \mathrm{~S}$ rRNA genes permitted the identification of the taxonomic position of that morphologically homogeneous group of colony (called LBMP soil-BR), and of the four evaluated strains. These results coincided with those reported by Depret et al. (2004), who suggested that the intergenic space was efficient for Rhizobium leguminosarum strain identification.

Based on known sequences for this intergenic space, LBMP soil-BR was identified as Rhizobium sp., with 94\% similarity to accession AF364839.1 (GenBank). LBMP soil-BR was different from the strains evaluated in this work (Figure 1). Among the four evaluated strains, LBMP-4BR and LBMP-4VE were identified as Rhizobium tropici, with 93 and 97\% similarity with accessions AY491966.1 and DQ682654.1 (GenBank), respectively. However, these strains formed groups with different phylogenetic positions (Figure 1).

The presence of $R$. tropici, in both Brazilian and Venezuelan isolates, confirms the results obtained by Martínez-Romero et al. (1991), which emphasized that this species seems to be native to tropical regions of South America. Similarly, Pinto et al. (2007) showed that the majority of very effective rhizobia isolated from common bean field-grown plants were $R$. tropici.
The LBMP-12BR strain had 96\% similarity with Rhizobium etli (GenBank accession AY491965.1), and LBMP-3VE was similar to Rhizobium leguminosarum with 94\% similarity with AY491959.1 (GenBank). Nonetheless, on the phylogenetic tree generated from this study, the latter strain was phylogenetically closer to $R$. etli (Figure 1). The results of the phylogenetic analysis of intergenic space sequences placed these strains within the same group formed by $R$. leguminosarum and $R$. etli, confirming that these species are closely related (Santillana et al., 2008).

Several authors have evidenced that the variability among species which nodulate common bean is due to soil type or study area, among other factors. In this context, Depret et al. (2004) observed a decrease of $R$. leguminosarum in a soil submitted to corn monoculture. This result may explain the presence of the species $R$. tropici (LBMP-4BR) in a soil with corn monoculture in minimum tillage (Table 1). However, Andrade et al. (2002) observed a predominance of $R$. leguminosarum in acid soils that were not treated with lime. This is similar to results found in this study, as LBMP-3VE was isolated from acidic soil with no lime application.

In the second experiment, among the four new strains tested, LBMP-4BR and LBMP-12BR showed similar nodulation and fixation capacity as CIAT-899 and PRF-81 commercial strains, and had statistically identical levels of total nitrogen in grains. In addition, the response of these strains was not increased upon mixture with the PRF-81 commercial strain (Table 2).

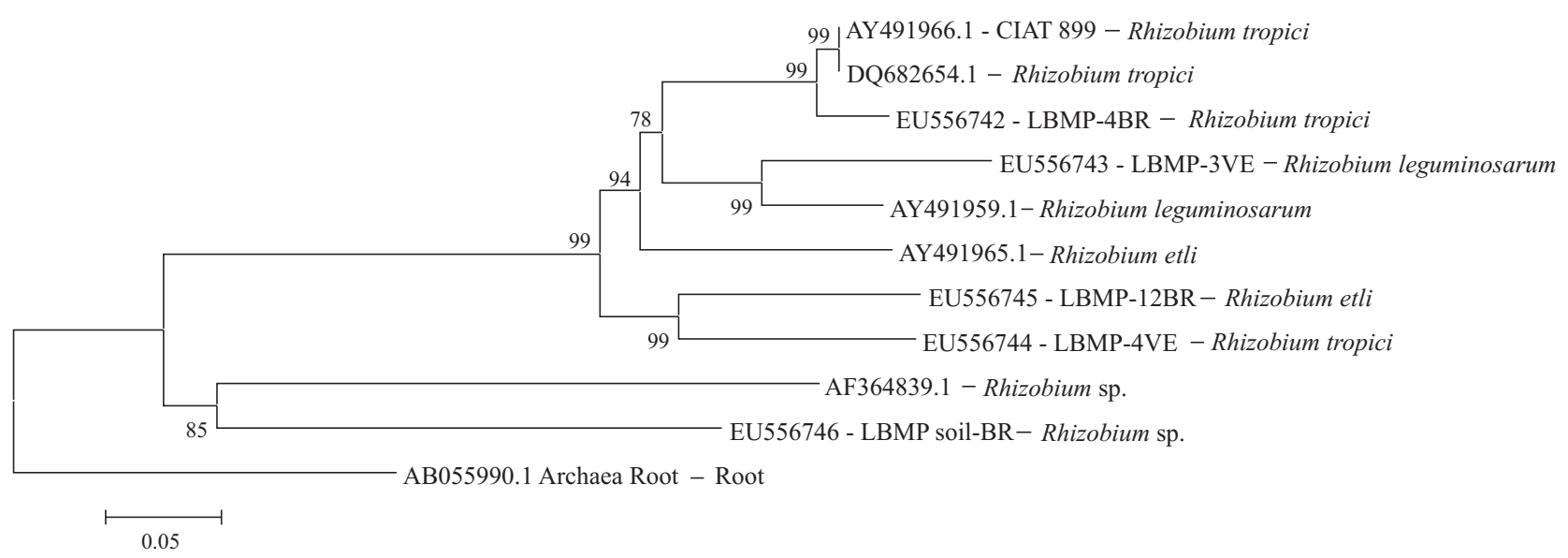

Figure 1. Neighbour joining phylogenetic tree of 16S-23S rRNA intergenic spaces of Rhizobium isolates from nodules of common bean plants. Values at branch points indicate bootstrap support higher than $75 \%$ from 1,000 pseudoreplicates. All sequences are numbered, and sequences in the database are indicated by the GenBank accession number. 
The mixture of LBMP-12BR strain ( $R$. etli) with PRF-81 (R. tropici) strain produced an antagonistic effect (Table 2). Similarly, Hassan et al. (2004) evidenced that the response upon mixing the strains was not always as good as the response to a single strain on inoculants. Hafeez et al. (2005) suggested that the antagonistic effect may be due to the production of bacteriocin, proteins or protein complexes with bacteriocidal activity directed against species closely related to the producer bacterium. The differential response showed among the inoculated strains alone, in the first experiment, compared to the second one, coincided with previous results that pointed out unstable behavior of inoculated strains in different environments (Mostasso et al., 2002; Hafeez et al., 2005; Soares et al., 2006).

The lowest common bean productivity, total nitrogen in grains, number of nodules and shoot dry weight were observed in the strains from Venezuela (Table 2). This suggests a possible environmental instability of these strains in Brazilian soil conditions, since one of them (LBMP-4VE), although identified as $R$. tropici, did not show a positive response in the acid soil evaluated (pH 5.9). This was unexpected, because Mostasso et al. (2002) emphasized that $R$. tropici is a good choice for acid soils with high temperatures, and Pinto et al. (2007) found that this species exhibited strong competitiveness, tolerance of stressful environmental conditions and genetic stability.

Mixture of the commercial strains, CIAT-899 and PRF-81, did not produce a statistically high response compared to the response of these strains alone. These results differed from those found by Hungria et al. (2000), which observed that, in Brazil, a mixture of these commercial strains caused a positive response to inoculation.

Low grain productivity, total nitrogen in grains, shoot dry weight and poor nodulation were observed for the uninoculated control treatment without nitrogen (Table 2). These results permitted to affirm that the native rhizobia population (identified as Rhizobium sp.) was inefficient in the nitrogen fixation, with low ability to nodulate common bean. Soares et al. (2006) obtained similar results for uninoculated plants without nitrogen treatment.

Like Soares et al. (2006), the control uninoculated treatment with $70 \mathrm{~kg} \mathrm{ha}^{-1} \mathrm{~N}$ inhibited nodulation, considering that this treatment showed the lowest number and dry weight of nodules (Table 2). However, this treatment had the highest grain productivity of common bean plants, likely due to the efficient use of $\mathrm{N}$, since the loss of nitrogen occurs mainly due to excesses of rain or irrigation, which causes lixiviation of the fertilizer (Straliotto et al., 2002), but, in the present study, an efficient drop irrigation system was used.

Table 2. Number of nodules (NN), dry weight of nodules (DWN), shoot dry weight (SDW), shoot total nitrogen (STN), grain productivity per plant (PG), and total nitrogen in grains (TNG) of common bean, cv. Pérola, inoculated with Rhizobium strains, under greenhouse conditions ${ }^{(1)}$.

\begin{tabular}{|c|c|c|c|c|c|c|}
\hline Treatment & NN per plant & DWN & SDW & STN & $P G^{(1)}$ & TNG \\
\hline CIAT -899 & $95 a$ & $223 b$ & $4,833 c$ & $\frac{\text { g per } p}{119 c}$ & $17,017 \mathrm{~b}$ & $571 b$ \\
\hline PRF-81 & $81 b$ & $209 c$ & $4,800 \mathrm{c}$ & $125 \mathrm{c}$ & $16,140 b$ & $507 \mathrm{~b}$ \\
\hline LBMP-3VE & $67 \mathrm{c}$ & $190 \mathrm{c}$ & $4,433 d$ & $114 b$ & $14,033 \mathrm{c}$ & $437 \mathrm{c}$ \\
\hline LBMP-4VE & $63 d$ & $190 \mathrm{c}$ & $4,466 \mathrm{~d}$ & $116 b$ & $14,967 \mathrm{c}$ & $479 c$ \\
\hline LBMP-4BR & $77 b$ & $192 \mathrm{c}$ & $4,800 \mathrm{c}$ & $135 c$ & $16,567 b$ & $545 b$ \\
\hline LBMP-12BR & $58 \mathrm{~d}$ & $172 \mathrm{c}$ & $4,733 c$ & $134 \mathrm{c}$ & $15,733 b$ & $518 b$ \\
\hline CIAT -899 x PRF-81 & $72 \mathrm{c}$ & $224 b$ & $5,200 b$ & $145 \mathrm{a}$ & $18,967 \mathrm{~b}$ & $616 b$ \\
\hline LBMP-3VE x PRF-81 & $68 \mathrm{c}$ & $195 \mathrm{c}$ & $4,866 \mathrm{c}$ & $133 \mathrm{c}$ & $18,133 b$ & $585 b$ \\
\hline LBMP-4VE x PRF-81 & $61 d$ & $196 \mathrm{c}$ & $4,900 \mathrm{c}$ & $132 \mathrm{c}$ & $17,867 b$ & $570 \mathrm{~b}$ \\
\hline LBMP-4BR x PRF-81 & $73 c$ & $229 a$ & $5,600 \mathrm{a}$ & $151 \mathrm{a}$ & $19,187 b$ & $613 b$ \\
\hline LBMP-12BR x PRF-81 & $47 \mathrm{e}$ & $149 \mathrm{e}$ & $4,266 \mathrm{~d}$ & $96 \mathrm{~d}$ & $12,667 \mathrm{c}$ & $405 c$ \\
\hline Control without nitrogen & $30 \mathrm{f}$ & $33 f$ & $1,933 \mathrm{e}$ & $39 \mathrm{e}$ & $7,667 d$ & $231 d$ \\
\hline Control with nitrogen & $11 \mathrm{~g}$ & $21 \mathrm{~g}$ & $5,533 \mathrm{a}$ & $148 \mathrm{a}$ & $23,333 \mathrm{a}$ & $799 a$ \\
\hline CV $(\%)$ & 15.71 & 16.15 & 12.35 & 11.2 & 9.16 & 15.71 \\
\hline
\end{tabular}

${ }^{(1)}$ Within each column, means followed by the same letters do not differ by Scott-Knott test, at $5 \%$ of probability. 


\section{Conclusions}

1. The native population present in the studied soil is Rhizobium sp., and it is inefficient in nitrogen fixation.

2 . The genetic characterization of the four new Rhizobium strains showed that they are Rhizobium tropici, R. Leguminosarum, and R. etli.

3. Sequencing of the intergenic space between the 16S and 23S rRNA genes allows for the characterization of the Rhizobium species on common bean.

4. The new strains LBMP-4BR and LBMP-12BR are among the ones with greatest nodulation and fixation capacity, and exhibit differential responses when mixed to PRF-81.

\section{Acknowledgements}

To Fundação de Apoio à Pesquisa do Estado de São Paulo, for financial support; to Consejo de Desarrollo Científico e Humanístico de La Universidad Central de Venezuela, for scholarship; to Dr. Orlando Di Mauro, for allowing access to the greenhouse facilities; to MSc. Eliamar Nascimbem Pedrinho, for help with sequencing.

\section{References}

ALTSCHUL, S.F.; MADDEN, T.L.; SCHAFFER, A.A.; ZHANG, J.; ZHANG, Z.; MILLER, W.; LIPMAN, D.J. Gapped BLAST and PSI-BLAST: a new generation of protein database search programs. Nucleic Acids Research, v.25, p.3389-3402, 1997.

ANDRADE, D.S.; MURPHY, P.J.; GILLER, K.E. The diversity of Phaseolus-nodulating rhizobial populations is altered by liming of acid soils planted with Phaseolus vulgaris L. in Brazil. Applied and Environmental Microbiology, v.68, p.4025-4034, 2002.

BERINGER, J.E. R factor transfer in Rhizobium leguminosarum. Journal of General Microbiology, v.84, p.188-198, 1974.

CHUEIRE, L.M.O.; BANGEL, E.V.; MOSTASSO, F.L.; CAMPO, R.J.; PEDROSA, F.O.; HUNGRIA, M. Classificação taxonômica das estirpes de rizóbio recomendadas para as culturas da soja e do feijoeiro baseada no seqüenciamento do gene 16S rRNA. Revista Brasileira de Ciência do Solo, v.27, p.833-840, 2003.

DEPRET, G.; HOUOT, S.; ALLARD, M.R.; BREUIL, M.C.; NOUAÏM, R.; LAGUERRE, G. Long-term effects of crop management on Rhizobium leguminosarum biovar viciae populations. FEMS Microbiology Ecology, v.51, p.87-97, 2004.

FERREIRA, D.F. SISVAR: sistema de análise de variância para dados balanceados, versão 4.0. Lavras: DEX/UFLA, 1999.

FERREIRA, M.C.; HUNGRIA, M. Recovery of soybean inoculant strains from uncropped soils in Brazil. Field Crops Research, v.79, p.139-152, 2002.
GIBSON, A.H. Evaluation of nitrogen fixation by legumes in the greenhouse and growth chamber. In: ELKAN, G.H. Symbiotic nitrogen fixation technology. New York: Marcel Dekker, 1987. p.321-369.

GORDON, D.; ABAJIAN, C.; GREEN, P. Consed: a graphical tool for sequence finishing. Genome Research, v.8, p.195-202, 1998.

HAFEEZ, F.Y.; NAEEM, F.I.; NAEEM, R.; ZAIDI, A.H.; MALIK, K.A. Symbiotic effectiveness and bacteriocin production by Rhizobium leguminosarum bv. viciae isolated from agriculture soils in Faisalabad. Environmental and Experimental Botany, v.54, p.142-147, 2005.

HALL, T.A. BioEdit: a user-friendly biological sequence alignment editor and analysis program for Windows 95/98/NT. Nucleic Acids Symposium Series, v.41, p.95-98, 1999.

HASSAN, M.; WAFAA, M.A.; DESSOUKY, A. Performance of Phaseolus bean rhizobia in soils from the major production sites in the Nile Delta. Comptes Rendus Biologies, v.327, p.445-453, 2004.

HUNGRIA, M.; ANDRADE, D. de S.; CHUEIRE, L.M. de O.; PROBANZA, A.; GUTTIERREZ-MANERO, F.J.; MEGÍAS, M. Isolation and characterization of new efficient and competitive bean (Phaseolus vulgaris L.) rhizobia from Brazil. Soil Biology and Biochemistry, v.32, p.1515-1528, 2000.

HUNGRIA, M.; CAMPO, R.J.; MENDES, I.C. Benefits of inoculation of the common bean (Phaseolus vulgaris) crop with efficient and competitive Rhizobium tropici strains. Biology and Fertility of Soils, v.39, p.88-93, 2003.

KUMAR, S.; TAMURA, K.; JAKOBSEN, I.B.; NEI, M. Mega 2: molecular evolutionary genetics analysis software. Bioinformatics, v.17, p.1244-1245, 2001.

LAGUERRE, G.; MAVINGUI, P.; ALLARD, M.R.; CHARNAY, M.P.; LOUVRIER, P.; MAZURIER, S.I.; RIGOTTIER-GOIS, L.; AMARGER, N. Typing of rhizobia by PCR-DNA fingerprinting and PCR-restriction fragment length polymorphism analysis of chromosomal and symbiotic gene regions: application to Rhizobium leguminosarum and its different biovars. Applied and Environmental Microbiology, v.62, p.2029-2036, 1996.

MARTÍNEZ-ROMERO, E.; SEGOVIA, E.; MERCANTE, F.M.; FRANCO, A.A.; GRAHAM, P.H.; PARDO, M.A. Rhizobium tropici, a novel species nodulating Phaseolus vulgaris L. beans and Leucaena sp. trees. International Journal of Systematic Bacteriology, v.41, p.417-426, 1991.

MOSTASSO, L.; MOSTASSO, F.L.; DIAS, B.G.; VARGAS, M.A.T.; HUNGRIA, M. Selection of bean (Phaseolus vulgaris L.) rhizobial strains for the Brazilian Cerrados. Field Crops Research, v.73, p.121-132, 2002.

OLIVEIRA, I.P. de; FAGERIA, N.K.; THUNG, M. Adubações corretivas e de manutenção. In: AIDAR, H.; KLUTHCOUSKI, J.; STONE, L.F. (Ed.). Produção do feijoeiro-comum em várzeas tropicais. Santo Antônio de Goiás: Embrapa Arroz e Feijão, 2002. p.170-188.

PINTO, F.G.S.; HUNGRIA, M.; MERCANTE, F.M. Polyphasic characterization of Brazilian Rhizobium tropici strains effective in fixing $\mathrm{N}_{2}$ with common bean (Phaseolus vulgaris L.). Soil Biology and Biochemistry, v.39, p.1851-1864, 2007. 
RAPOSEIRAS, R.; MARRIEL, I.E.; MUZZI, M.R.S.; PAIVA, E.; PEREIRA FILHO, I.A.; CARVALHAIS, L.C.; PASSOS, R.V.M.; PINTO, P.P.; SÁ, N.M.H. de. Rhizobium strains competitiveness on bean nodulation in Cerrado soils. Pesquisa Agropecuária Brasileira, v.41, p.439-447, 2006.

SAMBROOK, J.; FRITSCH, E.F.; MANIATIS, T. Molecular cloning: a laboratory manual. $2^{\text {nd }}$ ed. New York: Cold Spring Harbor Laboratory, 1989. 545p.

SANTILLANA, N.; RAMÍREZ-BAHENA, M.H.; GARCÍAFRAILE, P.; VELÁZQUEZ, E.; ZÚÑIGA, D. Phylogenetic diversity based on $r r s, a t p D$, recA genes and $16 \mathrm{~S}-23 \mathrm{~S}$ intergenic sequence analyses of rhizobial strains isolated from Vicia faba and Pisum sativum in Peru. Archives of Microbiology, v.189, p.239-247, 2008.

SILVA, D.J.; QUEIROZ, A.C. Análise de alimentos: métodos químicos e biológicos. 3.ed. Viçosa: UFV, 2006. 235p.

SOARES, A.L. de L.; FERREIRA, P.A.A.; PEREIRA, J.P.A.R.; VALE, H.M.M. do; LIMA, A.S.; ANDRADE, M.J.B. de; MOREIRA, F.M. de S. Eficiência agronômica de rizóbios selecionados e diversidade de populações nativas nodulíferas em Perdões (MG). II-Feijoeiro. Revista Brasileira de Ciência do Solo, v.30, p.803-811, 2006.
STRALIOTTO, R.; TEIXEIRA, M.G.; MERCANTE, F.M. Fixação biológica de nitrogênio. In: AIDAR, H.; KLUTHCOUSKI, J.; STONE, L.F. (Ed.). Produção do feijoeiro-comum em várzeas tropicais. Santo Antônio de Goiás: Embrapa Arroz e Feijão, 2002. p.121-153.

THOMPSON, J.D.; GIBSON, T.J.; PLEWNIAK, F.; JEANMOUGIN, F.; HIGGINS, D.G. The CLUSTAL_X windows interface: flexible strategies for multiple sequence alignment aided by quality analysis tools. Nucleic Acids Research, v.25, p.4876-4882, 1997.

VINCENT, J.M. A manual for the practical study of root nodule bacteria. Oxford: Blackwell Scientific Publications, 1970. 164p. (IBP Handbook, n.15).

YOKOYAMA, L.P.; DEL PELOSO, M.J.; DI STEFANO, J.G.; YOKOYAMA, M. Nível de aceitabilidade da cultivar de feijão Pérola: avaliação preliminar. Santo Antônio de Goiás: Embrapa Arroz e Feijão, 1999. 20p. (Embrapa Arroz e Feijão. Documentos, 98).

YOUNG, J.M.; PARK, D.; WEIR, B.S. Diversity of $16 \mathrm{~S}$ rDNA sequences of Rhizobium spp. Implications for species determinations. FEMS Microbiology Letters, v.238, p.125-131, 2004.

Received on May 14, 2008 and accepted on August 8, 2008 